\title{
PENERAPAN SISTEM TERTANAM UNTUK MONITORING KANDANG AYAM BROILER
}

\author{
Fathurrahmani $^{1}$, Wiwik Kusrini ${ }^{2}$, Khairul Anwar Hafizd ${ }^{3}$, Arif Supriyanto ${ }^{4}$ \\ 1,2,3,4 Politeknik Negeri Tanah Laut \\ Email : fathurrahmani@politala.ac.id
}

\begin{abstract}
ABSTRAK
Ayam broiler merupakan hewan ternak yang pertumbuhannya cepat dan dipengaruhi oleh kondisi lingkungan. Kandang merupakan bagian dari pengelolaan ternak ayam broiler yang sangat penting untuk diperhatikan, terutama mengenai suhu udara, kelembaban udara dan kadar amonia. Oleh karenanya perlu dilakukan monitoring secara rutin. Dalam penelitian ini penulis membuat sebuah sistem tertanam yang bisa mendeteksi suhu, kelembaban dan kadar amonia kandang. Sistem ini bekerja dengan cara mengirimkan suhu, kelembaban dan informasi gas amonia secara rutin satu hari sekali ke pengelola kandang melalui pesan singkat (SMS), atau informasi akan dikirimkan apabila kondisi lingkungan berada diatas/dibawah ambang batas. Sistem tertanam dibangun menggunakan pengendali mikro, sensor suhu dan kelembaban udara serta sensor amonia. Pengendali mikro memakai Arduino. Sensor suhu dan kelembaban udara menggunakan DHT11, sedangkan sensor kadar amonia menggunakan MQ-135. Komunikasi sistem tertanam menggunakan modul GSM SIM800L, modul ini bertanggung jawab untuk mengirimkan kondisi lingkungan kandang kepada pengelola melalui SMS. Pengujian dilakukan dengan dua tahap yaitu fungsionalitas dan konektivitas. Uji fungsionalitas membuktikan bahwa sensor dapat menghasilkan informasi suhu udara, kelembaban udara dan kadar amonia dengan cara membandingkannya dengan alat konvensional. Uji konektivitas membuktikan bahwa modul GSM SIM800L dapat mengirimkan data monitoring setiap hari dan kondisi tertentu.
\end{abstract}

Kata Kunci : sistem tertanam, ayam broiler, monitoring, amonia, sms .

\begin{abstract}
Broilers are fast growing animals that are influenced by environmental conditions. Routine monitoring is needed, especially temperature, humidity and ammonia levels. In this study, the authors propose an embedded system that can detect temperature, humidity and ammonia levels. This system works by sending temperature, humidity and ammonia gas information routinely once a day to the henhouse operator via text message (SMS), or information will be sent if environmental conditions are above/below the threshold. The embedded system was built using microcontrollers, temperature and humidity sensors as well as ammonia sensors. The microcontroller uses Arduino. Temperature and humidity sensors use DHT11, while the ammonia level sensor uses MQ-135. Embedded system communication uses the GSM SIM800L module, this module is responsible for sending the henhouse environmental conditions to the operator via SMS. Testing is done in two stages, namely functionality and connectivity. The functionality test proves that the sensor can produce information on temperature, humidity and ammonia levels by comparing it with conventional tools. The connectivity test proves that the GSM SIM800L module can send monitoring data every day and certain conditions.
\end{abstract}

Keyword: embedded systems, broiler, monitoring, ammonia, SMS

Author Korespondensi (Fathurrahmani)

Email :fathurrahmani@politala.ac.id _

\section{PENDAHULUAN}

Peternakan merupakan bisnis yang berkembang dengan sangat pesat serta memiliki permintaan yang cukup tinggi terutama unggas seperti ayam broiler. Hal yang perlu diperhatikan dalam berternak ayam broiler salah satunya adalah kondisi lingkungan kandang. Kondisi kandang harus dijaga seoptimal mungkin sehingga ayam berada dalam kondisi yang nyaman sesuai dengan umur pertumbuhannya. Variabel yang dioptimalkan tersebut adalah suhu, kelembaban udara dan kadar ammonia. Berdasarkan [1] suhu dan kelembaban udara harus berada pada nilai tertentu sehingga 
membuat ayam merasa nyaman dikandang.

Tabel 1. Suhu dan Kelembaban Udara yang Nyaman Bagi Ayam Broiler [1]

\begin{tabular}{ccc}
\hline \multicolumn{3}{c}{ Tingkat Akurasi } \\
\hline $\begin{array}{c}\text { Umur } \\
\text { (hari) }\end{array}$ & Suhu $\left({ }^{\circ} \mathrm{C}\right)$ & Kelembaban $(\%)$ \\
\hline 1 & $32-29$ & $60-70$ \\
3 & $30-27$ & $60-70$ \\
6 & $28-25$ & $60-70$ \\
9 & $27-25$ & $60-70$ \\
12 & $26-25$ & $60-70$ \\
$\geq 15$ & $24-25$ & $60-70$ \\
\hline
\end{tabular}

Apabila suhu dan kelembaban tidak dijaga sesuai dengan standar yang sudah ditetapkan maka akan menggangu pertumbuhan ayam broiler dan pastinya juga akan mempengaruhi produktivitas kandang. Jadi berdasarkan [1], kondisi lingkungan tidak boleh terlalu dingin atau terlalu panas dan tidak boleh terlalu lembab atau terlalu kering.

Selain suhu dan kelembaban hal lain yang perlu diperhatikan adalah kadar gas didalam kandang, terutama amonia. Amonia adalah gas yang sangat mudah dirasakan oleh indra penciuman. Pada konsentrasi yang tinggi amonia dapat menyebabkan iritasi membran mucosa saluran pernapasan, konjungtiva dan kornea mata. Kerusakan pada membran mukosa tersebut dapat menyebabkan infeksi bakteri, terutama yang disebabkan oleh $E$. coli. Konsentrasi ammonia yang tinggi juga dapat mengakibatkan efek negatif pada daya tahan, berat badan dan sistem kekebalan ayam. Menurut [2] kadar maksimum amonia didalam kandang unggas adalah $25 \mathrm{ppm}$.

Monitoring merupakan kegiatan yang rutin dilakukan dalam mengelola kandang ayam broiler. Salah satu kegiatannya yakni mengumpulkan data suhu dan kelembaban udara. Secara konvensional data ini dikumpulkan oleh pekerja lapangan atau PPL dengan cara langsung datang ke kandang. Dalam kasus ini, waktu dan lokasi menjadi variabel yang mempunyai biaya tinggi. Hal ini disebabkan oleh lokasi kandang yang tersebar dibeberapa lokasi dan biasanya berada jauh dari perkotaan dan pemukiman warga. Hal ini menyebabkan pengambilan keputusan akan menjadi lebih lambat karena menunggu hasil pengumpulan data dari PPL.

Berdasarkan permasalahan tersebut muncul pertanyaan bagaimana jika data didapatkan secara real-time dan rutin tanpa harus ke datang kandang langsung. Pertanyaan tersebut bisa terjawab dengan menerapkan sistem tertanam. Sistem tertanam (embedded system) adalah sistem komputer yang dirancang untuk menyelesaikan tugas spesifik tertentu [3]. Embedded berarti sesuatu yang melekat pada hal lain. Sistem tertanam dapat dianggap sebagai sistem perangkat keras komputer yang memiliki perangkat lunak yang tertanam di dalamnya. Sistem tertanam dapat berupa sistem independen atau dapat menjadi bagian dari sistem besar. Sistem tertanam adalah sistem berbasis mikrokontroler atau mikroprosesor yang dirancang untuk melakukan tugas tertentu. Misalnya, alarm kebakaran, dimana sistem hanya mengenali asap sebagai ancaman. Sistem tertanam memiliki tiga komponen [4]:

a. perangkat keras;

b. perangkat lunak aplikasi;

c. real time operating system (RTOS) yang mengawasi perangkat lunak aplikasi dan menyediakan mekanisme untuk membiarkan prosesor menjalankan proses sesuai penjadwalan dengan mengikuti rencana untuk mengontrol latensi. RTOS mendefinisikan cara sistem bekerja. Ini menetapkan aturan selama pelaksanaan program aplikasi. Sistem tertanam skala kecil mungkin tidak memiliki RTOS.

Jadi dapat didefinisikan bahwa sistem tertanam adalah sistem yang sebagai berbasis mikrokontroler, lunak, reliable dan didapat diakses secara real-time.

Pada penelitian ini penulis merancang dan membuat sistem tertanam yang mempunyai tugas untuk merekam suhu, kelembaban udara dan informasi kadar amonia secara real-time dan rutin setiap hari, kemudian dilanjutkan ke PPL. Data dikirim ke PPL melalui pesan singkat (SMS). Selain dikirim secara rutin, data juga dikirim jika lingkungan kandang pada kondisi tertentu sesuai standar [1] dan [2]. Komunikasi data bisa lebih efektif dan pengolahannya bisa lebih bervariatif jika menggunakan jaringan internet, seperti penelitian yang sudah dilakukan oleh [5]. 
Namun apabila pendekatan [5] diterapkan pada penelitian ini akan terkendala oleh infrastruktur, karena belum meratanya jaringan internet yang stabil disetiap lokasi kandang. Oleh sebab itu, data dikirimkan melalui SMS.

Sistem tertanam yang dibuat pada penelitian ini memanfaat Arduino sebagai pengendali mikro (microcontroller). Arduino sendiri adalah perangkat keras yang bertugas untuk mengumpulkan data dari sensor kemudian mengolahnya [6].

Arduino adalah platform elektronik sumber terbuka yang didasarkan pada perangkat keras dan lunak yang mudah digunakan. Arduino dapat membaca input seperti suhu dan kelembaban udara dari suatu sensor kemudian mengubahnya menjadi output untuk mengaktifkan motor, menyalakan LED, mempublikasikan datanya secara daring. Arduino dapat dikendalikan dengan mengirimkan serangkaian instruksi ke mikrokontroler. Untuk menjalankan instruksi tersebut mikrokontroller di sisipkan algoritma dengan menggunakan bahasa pemrograman $\mathrm{C}$ memanfaatkan Arduino IDE [7]. Arduino telah banyak dimanfaatkan sebagai mikrokontroler untuk menyelesaikan masalah berbagai proyek ilmiah baik sederhana maupun kompleks. Telah dimanfaatkann oleh berbagai kalangan masyarakat mulai dari pelajar hingga peneliti professional. Hal ini yang mengakibatkan kuatnya komunitas sumber terbuka dari Arduino.

Arduino diciptakan oleh Ivrea Interaction Design Institute sebagai mikrokontroler yang dimanfaatkan untuk membuat suatu prototipe dengan fast development. Alat ini awalnya ditujukan untuk pemula yang tidak memiliki latar belakang dalam bidang elektronik dan pemrograman. Pengembangannya sekarang alat ini dimanfaatkan untuk kebutuhan dan tantangan baru yang lebih kompleks dibidang teknologi informasi seperti pengaplikasian Internet of Things, printer 3D, wearable things dan sistem tertanam [7].

Arduino sebagai mikrokontroler bisa diintegrasikan dengan berbagai macam sensor melalui pin input yang sudah disediakan. Diantaranya adalah sensor DHT11 dan MQ135. Sensor DHT11 adalah sensor yang bisa merekam data suhu dan kelembaban udara. Sensor MQ-135 adalah sensor yang bisa disa merekam gas-gas berbahaya diudara diantaranya adalah amonia (NH3). Tidak hanya sensor yang bisa dintegrasikan dengan dengan Arduino, modul perangkat keras seperti modul GSM juga bisa, pada penelitian ini peneliti menggunakan modul GSM SIM 800L sebagai alat komunikasi antara antara Arduino dengan ponsel PPL melalui SMS.

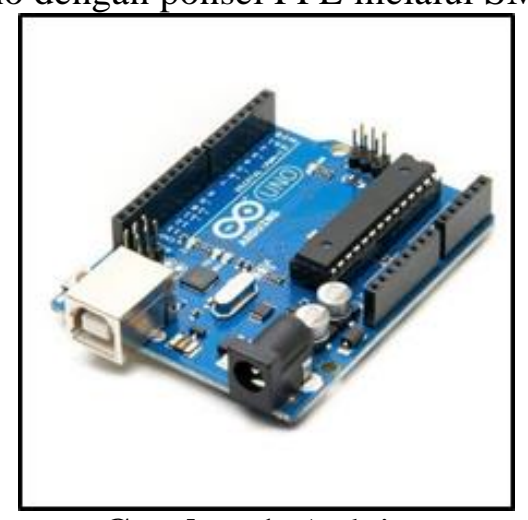

Gambar 1. Arduino

Data suhu dan kelembaban udara direkam dengan menggunakan bantuan sensor DHT11. Sensor DHT11 adalah sensor dengan kalibrasi sinyal digital yang mampu memberikan informasi suhu dan kelembaban udara. Sensor ini tergolong komponen yang memiliki tingkat stabilitas yang sangat baik serta fitur kalibrasi yang sangat akurat. Koefisien kalibrasi disimpan dalam one time-programable (OTP) program memory, sehingga ketika internal sensor mendeteksi sesuatu, maka module ini menyertakan koefisien tersebut dalam kalkulasinya dengan transimisi sinyal hingga 20 meter, dengan spesifikasi Supply Voltage: $+5 \mathrm{~V}$, Temperature range : $0-50{ }^{\circ} \mathrm{C}$ error of \pm $2{ }^{\circ} \mathrm{C}$, Humidity : $20-90 \% \mathrm{RH} \pm 5 \% \mathrm{RH}$ error. Prinsip kerjanya adalah memanfaatkan perubahan kapasitif perubahan posisi bahan dielektrik diantara kedua keping, pergeseran posisi salah satu keping dan luas keping yang berhadapan langsung [8].

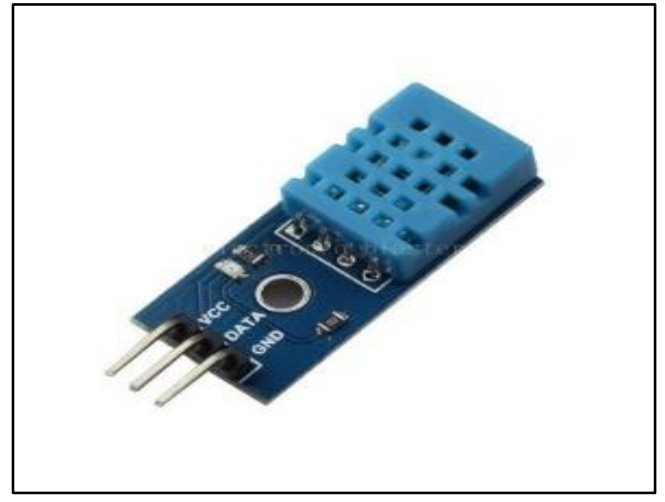

Gambar 2. Sensor DHT11 
Data kualitas udara kandang direkam menggunakan sensor MQ-135. Sensor gas MQ-135 adalah jenis sensor kimia yang sensitif terhadap senyawa NH3, NOx, alkohol, bensol, asap (CO), CO2 [9].

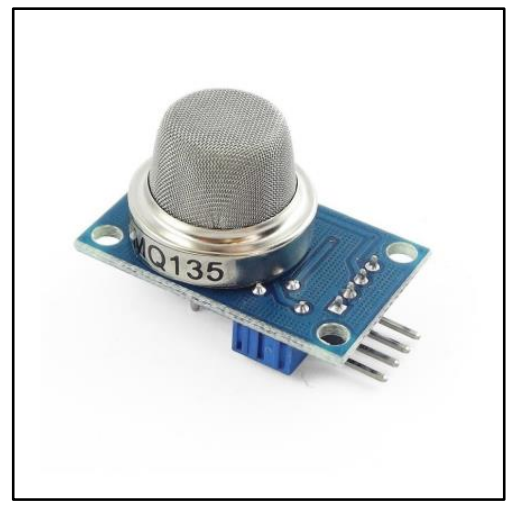

Gambar 3. Sensor MQ-135

Data rekaman dari setiap sensor di kirim ke ponsel PPL setelah datanya diolah di Arduino melalui modul GSM SIM800L. SIM800L adalah modul GSM/GPRS quad-band, yang bekerja pada frekuensi 850/900/1800/1900MHz. SIM800L memiliki fitur GPRS multi-slot kelas 12/kelas 10 (opsional) dan mendukung skema pengkodean GPRS. Dengan konfigurasi kecil $15.8 * 17.8 *$ $2.4 \mathrm{~mm}$, SIM800L dapat memenuhi hampir semua kebutuhan ruang dalam aplikasi pengguna, seperti ponsel pintar, PDA, dan perangkat seluler lainnya [10].

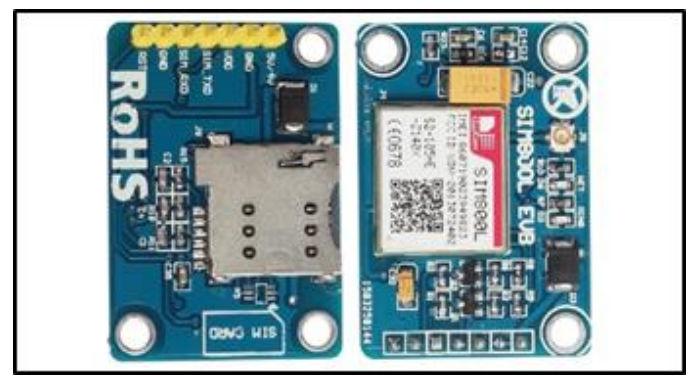

Gambar 4. Modul GSM SIM800L

Data dikirim secara rutin satu hari sekali dengan menggunakan Real Time Clock (RTC). RTC merupakan chip IC yang mempunyai fungsi menghitung waktu yang dimulai dari detik, menit, jam, hari, tanggal, bulan, hingga tahun dengan akurat. Untuk menjaga atau menyimpan data waktu yang telah di-ON-kan pada modul terdapat sumber catu daya sendiri yaitu baterai jam kancing, serta keakuratan data waktu yang ditampilkan digunakan osilator kristal eksternal Contoh yang dapat ditemui dalam kehidupan seharihari yaitu pada motherboard PC yang biasanya letaknya berdekatkan dengan chip BIOS. Difungsikan guna menyimpan sumber informasi waktu terkini sehingga jam akan tetap up to date walaupun komputer tersebut dimatikan [11].

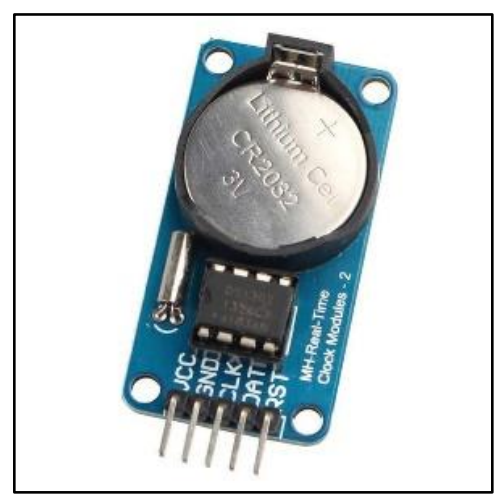

Gambar 5. RTC

\section{METODOLOGI}

Metode penelitian yang digunakan adalah metode waterfall. Metode waterfall menyediakan pendekatan pengembangan sistem secara sekuensial atau terurut dimulai dari analisis, desain, pengkodean, dan pengujian. Tahapan-tahapan dalam metode waterfall dapat dilihat pada gambar di bawah ini:

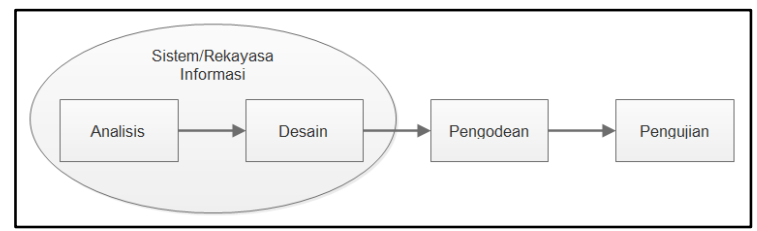

Gambar 6. Metode Waterfall [12]

Berikut penjelasan metode pengembangan sistem yang dilakukan:

1. Analisis Sistem

Ada beberapa tahapan dalam yang dilakukan dalam analisis sistem:

a. survey kandang ayam broiler untuk mengetahui kondisi lapangan dan melakukan analisa keperluan perangkat keras yang sesuai dengan kondisi lapangan;

b. wawancara kepada PPL untuk mengetahui kendala-kendala selama merekam data;

c. melakukan literature review untuk 
mengetahui state of the art teknologi yang digunakan dan melakukan filter terhadap teknologi yang siap untuk diterapkan terhadap kasus yang dihadapi;

d. menentukan perangkat keras dan lunak yang digunakan. Perangkat keras yang digunakan adalah pengendali mikro Arduino Uno, sensor DHT11, sensor MQ-135, modul GSM SIM800L, RTC, panel LCD dan power adapter. Perangkat lunak yang digunakan adalah Arduino IDE, library untuk sensor-sensor dan modul GSM;

e. tools yang digunakan adalah notebook/PC dengan spesifikasi minimum intel core i3/sejenis, RAM 4GB dan ponsel GSM.

f. Menentukan ambang batas (threshold) untuk kelembaban, suhu dan amonia didalam udara yang optimal, sesuai dengan [1] dan [2].

g. Merancang algoritma:

- data suhu, kelembaban dan amonia dikirim setiap hari sekali;

- pemberitahuan dikirim jika suhu udara berada diatas ambang batas;

- pemberitahuan dikirim jika suhu udara berada dibawah ambang batas;

- pemberitahuan dikirim jika kelembaban udara berada diatas ambang batas;

- pemberitahuan dikirim jika kelembaban udara berada dibawah ambang batas;

- pemberitahuan dikirim jika amonia berada diatas ambang batas.

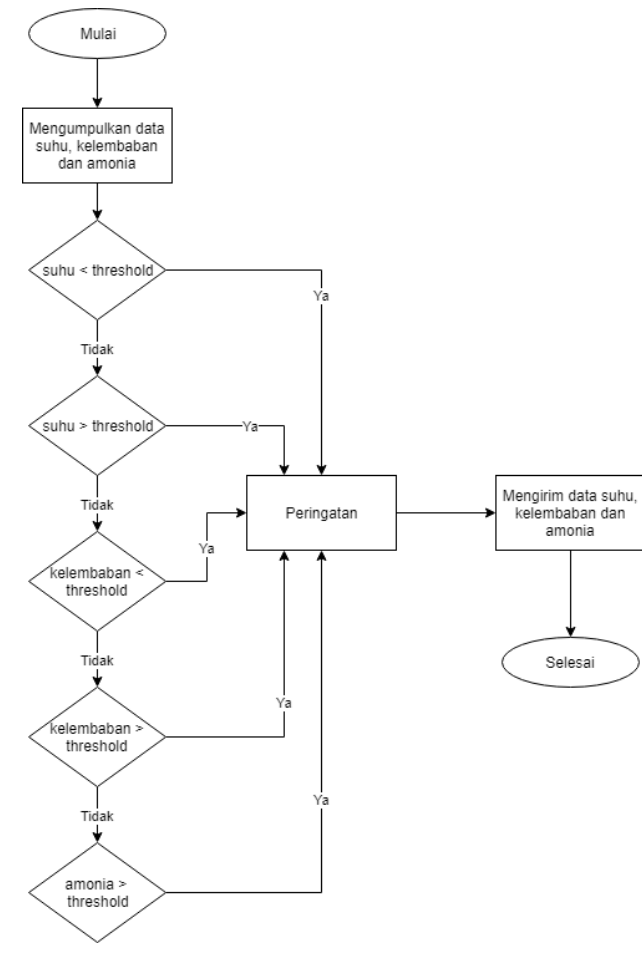

Gambar 7. Flowchart Algoritma Sistem

2. Desain

Desain terbagi atas 3 tahapan:

a. Desain case alat monitoring;

b. Desain rangkaian perangkat keras;

c. Desain algoritma program.

3. Pengkodeaan

Kegiatan untuk melakukan penulisan kode menggunakan IDE berdasarkan algoritma yang sudah didesain, melakukan compiling program dan menyisipkan program ke pengendali mikro.

4. Pengujian

Pengujian dilakukan menggunakan metode blackbox. Tahapan pengujiannya adalah :
a. pengujian/kalibrasi sensor (uji fungsionalitas);
b. pengujian kesesuaian jalannya alat dengan algoritma yang sudah dirancang (uji fungsionalitas dan uji konektivitas);

\section{HASIL DAN PEMBAHASAN}

Sistem tertanam dibuat menggunakan rangkaian komponen perangkat keras seperti gambar 8. Sensor DHT11 digunakan untuk merekam suhu dan kelembaban udara. Sensor MQ-135 untuk merekam kadar amonia. 
Konektivitas menggunakan modul GSM SIM800L. Pengaturan waktu pengiriman hasil rekaman data menggunakan RTC. Perangkat keras yang memproses komponen-komponen diatas adalah Arduino UNO. DHT11 cukup efektif untuk di gunakan pada penelitian ini, karena alat tersebut bisa menghasilkan dua data sekaligus yakni suhu dan kelembaban udara. Selain itu, DHT11 juga memiliki rentang nilai suhu dan kelembaban yang sesuai dengan aturan [1].

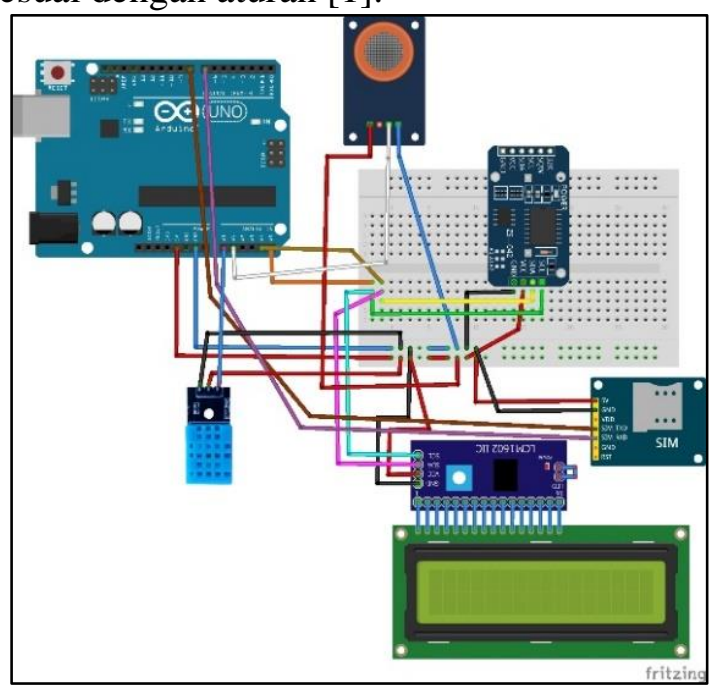

Gambar 8. Rangkaian Komponen Perangkat Keras

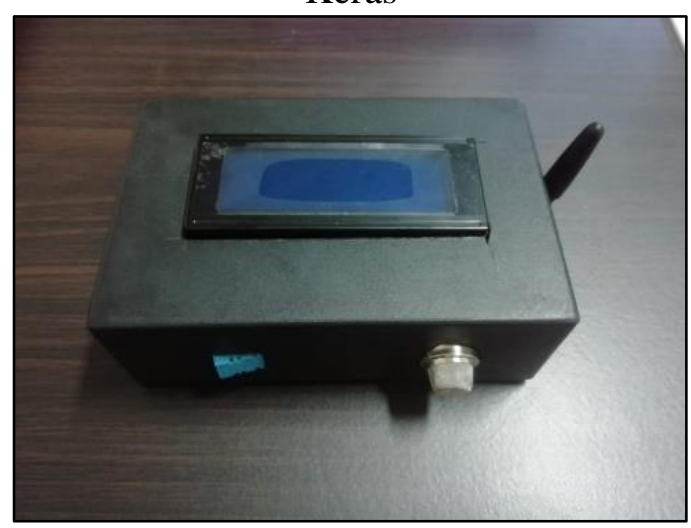

Gambar 9. Implementasi Alat

Semua sensor sebelum dirangkai di lakukan pengujian terlebih dahulu seperti tabel 2 , tabel 3 dan tabel 4. Pengujian dilakukan dengan cara melakukan perbandingan dengan alat konvensional yang biasa digunakan PPL.

Tabel 2. Pengujian Sensor Suhu Udara

\begin{tabular}{ccc}
\hline Uji Ke & $\begin{array}{c}\text { Sensor } \\
\left({ }^{\circ} \mathbf{C}\right)\end{array}$ & $\begin{array}{c}\text { Thermohygrometer } \\
\left({ }^{\mathbf{0}} \mathbf{C}\right)\end{array}$ \\
\hline $\mathbf{1}$ & 31,00 & 31,22 \\
\hline $\mathbf{2}$ & 31,00 & 31,22 \\
\hline
\end{tabular}

\begin{tabular}{ccc}
\hline $\mathbf{3}$ & 31,00 & 31,22 \\
\hline $\mathbf{4}$ & 31,00 & 31,22 \\
\hline $\mathbf{5}$ & 31,00 & 31,22 \\
\hline $\mathbf{6}$ & 31,00 & 31,22 \\
\hline $\mathbf{7}$ & 31,00 & 31,22 \\
\hline $\mathbf{8}$ & 31,00 & 31,22 \\
\hline $\mathbf{9}$ & 31,00 & 31,22 \\
\hline $\mathbf{1 0}$ & 31,00 & 31,22 \\
\hline Rerata & 31,00 & 31,22 \\
\hline
\end{tabular}

Berdasarkan hasil uji diatas, sensor suhu udara berhasil merekam data yang tidak jauh berbeda dengan alat konvensional. Terdapat perbedaan sebesar $0.22{ }^{\circ}$ Celcius. Perbedaan ini tidak begitu signifikan, sehingga dapat disimpulkan bahwa sensor bisa diimplementasikan pada penelitian ini.

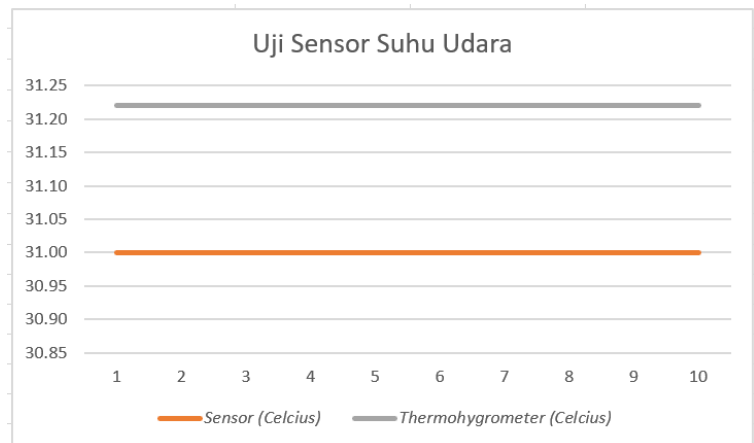

Gambar 10. Grafik Uji Sensor Suhu Udara

Tabel 3. Pengujian Sensor Kelembaban Udara

\begin{tabular}{ccc}
\hline Uji Ke & $\begin{array}{c}\text { Sensor } \\
\mathbf{( \% )}\end{array}$ & $\begin{array}{c}\text { Thermohygrometer } \\
(\mathbf{\%})\end{array}$ \\
\hline $\mathbf{1}$ & 71,00 & 71 \\
\hline $\mathbf{2}$ & 71,00 & 71 \\
\hline $\mathbf{3}$ & 71,00 & 71 \\
\hline $\mathbf{4}$ & 71,00 & 71 \\
\hline $\mathbf{5}$ & 71,00 & 71 \\
\hline $\mathbf{6}$ & 71,00 & 71 \\
\hline $\mathbf{7}$ & 71,00 & 71 \\
\hline $\mathbf{8}$ & 71,00 & 71 \\
\hline $\mathbf{9}$ & 71,00 & 71 \\
\hline $\mathbf{1 0}$ & 71,00 & 71 \\
\hline Rerata & 71,00 & 71 \\
\hline
\end{tabular}

Berdasarkan hasil uji diatas, sensor kelembaban udara berhasil merekam data yang sama dengan alat konvensional. Hal ini dapat disimpulkan bahwa sensor kelembaban udara bisa diimplementasikan pada penelitian ini. 


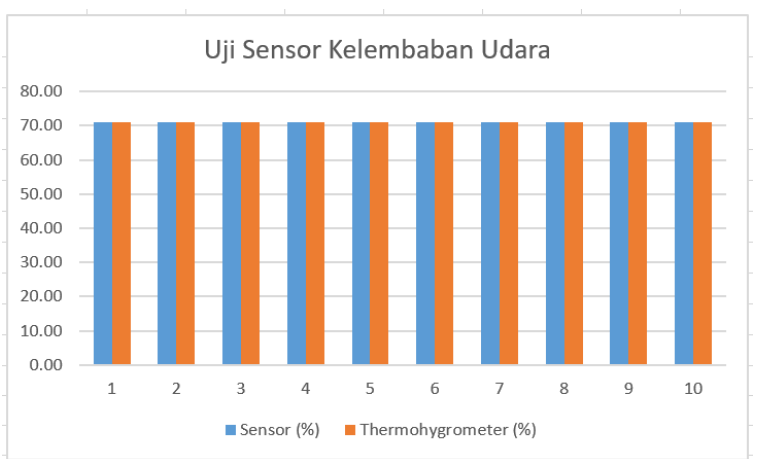

Gambar 11. Grafik Uji Sensor Kelembaban Udara

Tabel 4. Pengujian Sensor MQ-135

\begin{tabular}{ccc}
\hline $\begin{array}{c}\text { Uji Ke } \\
-\end{array}$ & $\begin{array}{c}\text { Sensor } \\
\text { (PPM) }\end{array}$ & $\begin{array}{c}\text { Amonia Detector } \\
\text { (PPM) }\end{array}$ \\
\hline $\mathbf{1}$ & 3 & 3,2 \\
\hline $\mathbf{2}$ & 3 & 3,2 \\
\hline $\mathbf{3}$ & 3 & 3,2 \\
\hline $\mathbf{4}$ & 3 & 3,2 \\
\hline $\mathbf{5}$ & 3 & 3,2 \\
\hline $\mathbf{6}$ & 3 & 3,2 \\
\hline $\mathbf{7}$ & 3 & 3,2 \\
\hline $\mathbf{8}$ & 3 & 3,2 \\
\hline $\mathbf{9}$ & 3 & 3,2 \\
\hline $\mathbf{1 0}$ & 3 & 3,2 \\
\hline Rerata & 3 & 3,2 \\
\hline
\end{tabular}

Berdasarkan hasil uji diatas, sensor amonia berhasil merekam data yang tidak jauh berbeda dengan alat konvensional. Terdapat perbedaan sebesar 0.2 PPM. Perbedaan ini tidak begitu signifikan, sehingga dapat disimpulkan bahwa sensor bisa diimplementasikan pada penelitian ini.

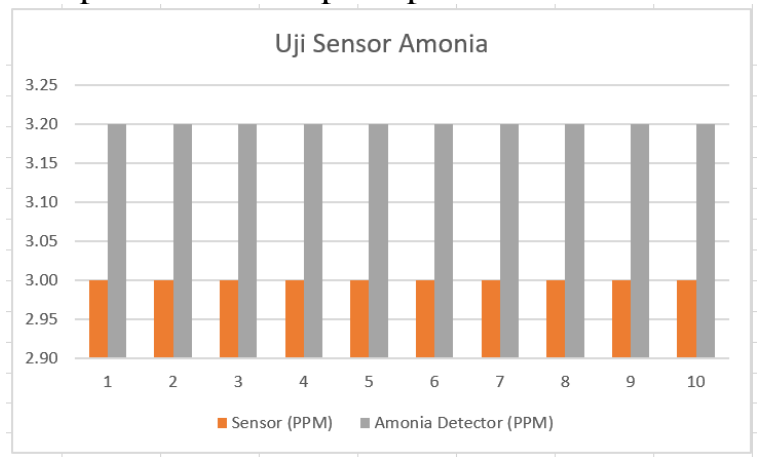

Gambar 12. Grafik Uji Sensor Amonia

Dari hasil pengujian sensor membuktikan bahwa semua sensor mempunyai perbedaan yang tidak signifikan dengan alat konvensional yang biasa digunakan bahkan ada yang mempunyai nilai yang sama. Sehingga sistem tertanam yang dibangun bisa mengandalkan sensor-sensor tersebut.

Algoritma yang disisipkan ke pengendali mikro juga diujikan menggunakan metode blackbox. Peneliti membagi dua pengujian, yaitu dari sisi fungsi sistem dan konektivitas.

Tabel 5. Pengujian Fungsionalitas Sistem Tertanam

\begin{tabular}{|l|l|c|}
\hline Skenario & \multicolumn{1}{|c|}{$\begin{array}{c}\text { Hasil yang } \\
\text { diharapkan }\end{array}$} & Kesimpulan \\
\hline Alat di & LCD & \\
operasikan & menampilkan & Valid \\
di kondisi & $\begin{array}{l}\text { lingkungan } \\
\text { rekaman suhu } \\
\text { udara }\end{array}$ & \\
\cline { 2 - 3 } & $\begin{array}{l}\text { LCD } \\
\text { menampilkan }\end{array}$ & \\
rekaman & Valid \\
& $\begin{array}{l}\text { kelembaban } \\
\text { udara }\end{array}$ & \\
\cline { 2 - 3 } & $\begin{array}{l}\text { LCD } \\
\text { menampilkan } \\
\text { kadar amonia }\end{array}$ & Valid \\
\hline $\begin{array}{l}\text { Alat di } \\
\text { panaskan } \\
\text { dengan } \\
\text { pengering } \\
\text { rambut }\end{array}$ & $\begin{array}{l}\text { LCD } \\
\text { menampilkan } \\
\text { rekaman suhu } \\
\text { udara naik dan } \\
\text { rekaman }\end{array}$ & \\
kelembaban & Valid \\
udara turun & \\
\hline $\begin{array}{l}\text { Alat } \\
\text { diletakkan } \\
\text { didalam } \\
\text { kandang } \\
\text { yang sudah } \\
\text { panen dan } \\
\text { belum } \\
\text { dibersihkan }\end{array}$ & $\begin{array}{l}\text { LCD menampilkan } \\
\text { kadar ammonia } \\
\text { naik }\end{array}$ & \\
\hline
\end{tabular}

Pengujian dari sisi fungsi (tabel 5) membuktikan bahwa pengintegrasian semua komponen berhasil dilakukan dan berjalan sesuai dengan algoritma yang diharapkan. Rekaman data yang dihasilkan oleh semua sensor diperbaharui setiap 1 detik dan ditampilkan langsung di LCD.

Tabel 6. Pengujian Konektivitas Sistem Tertanam

\begin{tabular}{|l|l|c|}
\hline Skenario & \multicolumn{1}{|c|}{$\begin{array}{c}\text { Hasil yang } \\
\text { diharapkan }\end{array}$} & Kesimpulan \\
\hline $\begin{array}{l}\text { Alat } \\
\text { dioperasik }\end{array}$ & $\begin{array}{l}\text { Alat } \\
\text { mengirimkan }\end{array}$ & Valid \\
an selama & $\begin{array}{l}\text { satu rekaman } \\
\text { x 24 jam }\end{array}$ & \\
data melalui & \\
\hline
\end{tabular}




\begin{tabular}{|c|c|c|}
\hline & $\begin{array}{l}\text { pesan singkat ke } \\
\text { pengelola } \\
\text { kandang }\end{array}$ & \\
\hline $\begin{array}{l}\text { Alat di } \\
\text { panaskan } \\
\text { sampai } \\
\text { dengan } \\
\text { ambang } \\
\text { batas yang } \\
\text { sudah } \\
\text { ditentukan }\end{array}$ & $\begin{array}{l}\text { Alat } \\
\text { mengirimkan } \\
\text { satu rekaman } \\
\text { data melalui } \\
\text { pesan singkat ke } \\
\text { pengelola } \\
\text { kandang }\end{array}$ & Valid \\
\hline $\begin{array}{l}\text { Alat di } \\
\text { dinginkan } \\
\text { sampai } \\
\text { dengan } \\
\text { ambang } \\
\text { batas yang } \\
\text { sudah } \\
\text { ditentukan }\end{array}$ & $\begin{array}{l}\text { Alat } \\
\text { mengirimkan } \\
\text { satu rekaman } \\
\text { data melalui } \\
\text { pesan singkat ke } \\
\text { pengelola } \\
\text { kandang }\end{array}$ & Valid \\
\hline $\begin{array}{l}\text { Alat di } \\
\text { berikan } \\
\text { hawa } \\
\text { basah } \\
\text { sampai } \\
\text { dengan } \\
\text { ambang } \\
\text { batas yang } \\
\text { sudah } \\
\text { ditentukan }\end{array}$ & $\begin{array}{l}\text { Alat } \\
\text { mengirimkan } \\
\text { satu rekaman } \\
\text { data melalui } \\
\text { pesan singkat ke } \\
\text { pengelola } \\
\text { kandang }\end{array}$ & Valid \\
\hline $\begin{array}{l}\text { Alat di } \\
\text { berikan } \\
\text { hawa } \\
\text { kering } \\
\text { sampai } \\
\text { dengan } \\
\text { ambang } \\
\text { batas yang } \\
\text { sudah } \\
\text { ditentukan }\end{array}$ & $\begin{array}{l}\text { Alat } \\
\text { mengirimkan } \\
\text { satu rekaman } \\
\text { data melalui } \\
\text { pesan singkat ke } \\
\text { pengelola } \\
\text { kandang }\end{array}$ & Valid \\
\hline $\begin{array}{l}\text { Alat di } \\
\text { beri kadar } \\
\text { amonia } \\
\text { sampai } \\
\text { dengan } \\
\text { ambang } \\
\text { batas yang } \\
\text { sudah } \\
\text { ditentukan }\end{array}$ & $\begin{array}{l}\text { Alat } \\
\text { mengirimkan } \\
\text { satu rekaman } \\
\text { data melalui } \\
\text { pesan singkat ke } \\
\text { pengelola } \\
\text { kandang }\end{array}$ & Valid \\
\hline
\end{tabular}

Pengujian dari sisi konektivitas menentukan data yang direkam berhasil di terima oleh ponsel pengelola kandang melalui pesan singkat. Skenario pengujian ini sesuai dengan hasil wawancara peneliti dengan PPL terkait dengan data yang diperlukan untuk pengambilan keputusan. Hasil dari pengujian ini terdapat di tabel 7 yang membuktikan bahawa sistem berjalan sesuai dengan harapan yang diinginkan.

\section{SIMPULAN DAN SARAN}

Berdasarkan hasil analisa, desain, penulisan kode dan pengujian, sistem tertanam ini bisa diimplementasi di kandang ayam broiler. Manfaat yang bisa dirasakan adalah monitoring kondisi lingkungan kandang ayam broiler terutama untuk suhu, kelembaban udara dan amonia bisa dilakukan dengan lebih cepat dan mudah walaupun lokasi kandang berada jauh dari perkotaan dan pemukiman warga serta tersebar di lokasi yang berbeda. Pemilihan sensor bisa dikatakan cukup efektif karena hanya dengan DHT11 dan MQ-135 sistem bisa menghasilkan 3 jenis data. Selain itu, rekaman data dari sensor sudah diujikan dengan cara membandingkannya dengan alat konvensional. Hasil pengujian sensor menunjukkan perbedaan yang tidak signifikan sehingga sensor bisa digunakan pada penelitian ini. Pemanfaatan modul GSM SIM800L juga bisa menjawab permasalahan pemilihan konektivitas mengingat ketidakmerataan infrastruktur jaringan internet disetiap lokasi kandang. Modul GSM mengirimkan setiap peringatan linkungan kandang melalui pesan SMS kepada pengelola.

Sistem ini perlu diujikan lagi kehandalannya terutama ketahanan terhadap penggunaan jangka panjang. Kemudahan konfigurasi pengguna juga menjadi tantangan sistem ini, karena sistem ini masih didesain secara hardcode.

\section{UCAPAN TERIMA KASIH}

Peneliti mengucapkan rasa terima kasih yang sebesar-besar kepada Politeknik Negeri Tanah Laut yang sudah menjadi penyandang dana dan juga kepada semua pihak yang terlibat dalam proses pengerjaan penelitian ini. Penelitian ini didanai dengan skema PD3 tahun 2019.

\section{REFERENSI}

[1] R. Aviagen, "Ross broiler management manual," Scotland, UK www. aviagen. 
pp, pp. 1-114, 2009.

[2] U. S. D. of Health, H. Services, and others, "NIOSH pocket guide to chemical hazards," in Niosh pocket guide to chemical hazards, US Department of Health and Human Services, 1997.

[3] T. Pernantin, "Sistem Tertanam (Embedded System)," Cetakan Pertama, Graha Ilmu, Yogyakarta, 2011.

[4] "Embedded Systems - Overview Tutorialspoint." [Online]. Available: https://www.tutorialspoint.com/embedde d_systems/es_overview.htm. [Accessed: 16-Sep-2019].

[5] A. A. G. Raj and J. G. Jayanthi, "IoTbased real-time poultry monitoring and health status identification," in 11th International Symposium on Mechatronics and its Applications, ISMA 2018, 2018.

[6] A. Kadir, Pemrograman Arduino dan Processing. Elex Media Komputindo, 2017.

[7] "Arduino - Introduction." [Online]. Available:

https://www.arduino.cc/en/Guide/Introdu ction. [Accessed: 16-Sep-2019].
[8] K. S. Budi and Y. Pramudya, "Pengembangan Sistem Akuisisi Data Kelembaban dan Suhu Dengan Menggunakan SENSOR DHT11 dan Arduino Berbasis IOT," in Prosiding Seminar Nasional Fisika (E-Journal), 2017, vol. 6, pp. SNF2017--CIP.

[9] H. Santoso, "Monster Arduino Panduan Praktis Belajar Arduino untuk Pemula." Malang: Elang Sakti, 2017.

[10] F. P. Himawan, U. Sunarya, and D. A. Nurmantris, "Perancangan Alat Pendeteksi Asap Berbasis Mikrokontoller, Modul Gsm, Sensor Asap, Dan Sensor Suhu," eProceedings Appl. Sci., vol. 3, no. 3, 2017.

[11] N. I. Zainal, K. A. Sidek, T. S. Gunawan, H. Manser, and M. Kartiwi, "Design and development of portable classroom attendance system based on Arduino and fingerprint biometric," in The 5th International Conference on Information and Communication Technology for The Muslim World (ICT4M), 2014, pp. 1-4.

[12] A. S. Rosa, "Rekayasa perangkat lunak terstruktur dan berorientasi objek," 2016. 